\title{
UNREASONABLY RISKY: WHY A NEGLIGENCE STANDARD SHOULD REPLACE THE BANKRUPTCY CODE'S FRAUDULENT INTENT ANALYSIS FOR GAMBLING DEBTS
}

\author{
Spencer H. Newman ${ }^{1}$
}

\begin{abstract}
INTRODUCTION
Gambling and bankruptcy often go hand-in-hand. The undeniable thrill of risking it all at a casino is often met by regret and the fear of the reality of finances. These situations have seemingly become more common as gambling has become more accessible with the rise of internet gambling, fantasy sports, and massive Powerball lotteries. Gambling, while seen as immoral by many, is a legal form of entertainment in most states across the country. And while access to the courts is a right to all Americans, discharging debts through a bankruptcy court is a privilege, not a right. This privilege is only available to the "honest but unfortunate debtor who is seeking a fresh start."2 Should people who incur large sums of debt by choosing to spend their money at casinos rather than, for example, debt from unexpected medical bills, be able to discharge such debt through Chapter 7 bankruptcy? Is a person taking out cash advances to use for gambling ever actually an "honest but unfortunate debtor?"

If the Bankruptcy Code (hereinafter, the "Code") truly exists solely for the "honest but unfortunate debtor," then why are gambling debts dischargeable? One could certainly argue that gambling is not necessarily dishonest, but it can also be said that gambling is often a financially irresponsible decision simply based on the statistical chances of losing money. A reasonably prudent person would not expect to take borrowed money into a casino and come out with the same opportunity to repay his or her creditor. Accordingly, portions of credit

1 The author is a May 2018 Juris Doctor Candidate at The University of Mississippi School of Law, an Associate Cases Editor of Volume 87 of the Mississippi Law Journal, and Vice Chair of the Ole Miss Moot Court Board. He received a Bachelor of Arts degree in History from Mississippi State University in 2015. The author wishes to thank Professor Ronald J. Rychlak for his guidance and expertise in Gaming Law. The author also wishes to thank Professor John M. Czarnetzky for his guidance and expertise in Bankruptcy Law.

2 In re O'Brien, 328 B.R. 669, 674 (Bankr. W.D.N.Y. 2005). Accord Grogan v. Garner, 498 U.S. 279, 286-87 (1991).
\end{abstract}


card debts or cash advances that were used for gambling should not be dischargeable under the Code under any circumstances.

Creditors regularly fight this problem by arguing that the debtor obtained the loan under false pretenses - or in other words - never intended on paying it back. ${ }^{3}$ Debtors often counter-argue that they did intend to repay the loan at the time, but their circumstances did not end up how they hoped. ${ }^{4}$ Casinos and state gaming commissions may certainly want to promote this idea, as the casinos stand to benefit if customers are allowed a fresh start after going broke from their gambling habits. ${ }^{5}$ When a person obtains a cash advancement from a bank or credit card company knowing that it will be used for gambling, the debtor "intends" to pay back the loan if he or she wins money, or at least breaks even. This is an assumption that a reasonably prudent person would not make, however, as the chances of winning are stacked against the gambler.

This article argues for a negligence per se standard in place of the current "fraudulent intent" analysis with respect to the dischargeability of gambling debts under the Code. The article explores the traditional gambling debt issues through the examination of case law and focuses on the issue of Chapter 7 bankruptcy for gamblers. Specifically, this article focuses on credit card debt or cash advances that were used for gambling purposes in brick-and-mortar casinos or through online gambling.

\section{BACKGROUND}

\section{A. Gambling Debt Statistics}

While approximately eighty-five percent of adults in the U.S. have gambled at some point in their life, an estimated two-million Americans meet the criteria for addictive or pathological gambling. ${ }^{6}$ Equally frightening is the fact that the average debt incurred by an adult male addicted to gambling is between $\$ 55,000$ and $\$ 90,000 .^{7}$ Unsurprisingly, over twenty percent of these addicted gamblers end up filing for bankruptcy due to their gambling losses. ${ }^{8}$

3 See In re Baum, 386 B.R. 649, 651-52 (Bankr. N.D. Ohio 2008); Novus Servs., Inc., v. Cron (In re Cron), 241 B.R. 1, 3, 5 (Bankr. S.D. Iowa 1999); La Capitol Federal Credit Union v. Melancon (In re Melancon), 223 B.R. 300, 300, 305 (Bankr. M.D. La. 1998); AT \& T Universal Card Servs. Corp. v. Totina (Matter of Totina), 198 B.R. 673, 676 (Bankr. E.D. La. 1996).

4 See In re Baum, 386 B.R. at 652; In re Cron, 241 B.R. at 4-5; In re Melancon, 223 B.R. at 320; Matter of Totina, 198 B.R. at 674, 680.

5 See generally Thomas H. Jackson, The Fresh Start Policy in Bankruptcy Law, 98 HARVARD L. REV. 1393, 1393 (1985) (noting how the bankruptcy discharge "frees the debtor's future income from the chains of previous debts").

${ }^{6}$ Max Fay, Gambling and Debt, DEBT.ORG, https://www.debt.org/advice/ gambling/ (last updated Aug. 25, 2016).

7 The average gambling debt of an adult female is much lower, around $\$ 15,000$. Id.

8 Id. 
This alarming rate of bankruptcy filings is enabled by one particular American specialty: easy access to credit.

Statistics show that roughly ninety percent of people suffering from gambling addiction withdraw cash advances from their personal credit card accounts to finance their gambling habits. ${ }^{9}$ This allows people with known gambling problems to take thousands of dollars in cash advancements into a casino and gamble it all away. Gamblers often engage in such conduct with an American safety net: the option of discharging that credit card debt through Chapter 7 bankruptcy.

While the Code already disfavors debtors racking up debt in anticipation of bankruptcy, the Code itself does not address falling into bankruptcy due to blatantly irresponsible spending. ${ }^{10}$ A long line of cases examine these issues, and specifically discuss whether a person can rack up debt because of a gambling problem to then simply avoid repayment through Chapter 7 bankruptcy.

\section{B. Traditional Gambling Debt Issues}

Casinos themselves run into problems with the Code when customers receive "markers" at the casino. ${ }^{11}$ Essentially, the casino issues a marker as a line of credit; the gamblers typically try to evade this debt through Chapter 7 bankruptcy, or by claiming that gambling debts in their state are unenforceable entirely. The Fifth Circuit's decision in the Aubin case is extremely troublesome for casinos and for anyone seeking to enforce a gambling debt. ${ }^{12}$ In 1987, Aubin, a Texas resident, visited the Carnival casino in the Bahamas. ${ }^{13}$ Aubin received markers from the casino and spent all of the markers on gambling. ${ }^{14}$ While gambling, Aubin lost roughly $\$ 25,000$ and left the casino

${ }^{9}$ Id.

${ }^{10} 11$ U.S.C. $\$ 526(\mathrm{a})(4)$ (2012). To be eligible for Chapter 7 bankruptcy, a debtor must satisfy a test which compares income and debt known as the "means test." 11 U.S.C. $\$ 707(b)(2)(A)(i)(I)-(I I)$. Some debtors may incur more debt in order to satisfy the Code's "means test" and be eligible for Chapter 7 bankruptcy; this action is not necessarily prohibited by the Code, but attorneys are prohibited from advising clients to do so.

${ }^{11}$ Carnival Leisure Indus. v. Aubin, Ltd., 53 F.3d 716, 717 n.1, 720 (5th Cir. 1995) ("A marker is a preprinted form, resembling a bank check or draft that a gambler with preapproved credit signs while on the casino floor in order to obtain tokens or chips to play a casino game. ... If the marker is not paid within 30 days by cash, check or casino chips, the casino presents the marker for payment, as a check or draft, to the bank designated by the player on the initial application for casino credit.").

12 See id. at 720.

${ }_{13}$ Carnival Leisure Indus., Ltd. v. Aubin, 938 F.2d 624, 624 (5th Cir. 1991).

14 Aubin could have spent the markers on food or other items at the casino, but chose not to. Id. 
with that amount in bank drafts. ${ }^{15}$ Aubin subsequently directed his bank to stop the payments, and the casino sued Aubin to enforce the debt owed for the markers. ${ }^{16}$

Unfortunately for the casino, the court held that gambling debts were unenforceable as a matter of public policy. ${ }^{17}$ This presented a serious problem for casinos, as this case was not a bankruptcy proceeding, but rather a basic civil enforcement suit. ${ }^{18}$ Because the state of Texas did not recognize gambling debts as enforceable debts, the casino had no way of receiving the money it had loaned to Aubin in order to play. ${ }^{19}$ While credit card companies may be able to enforce credit card debt that was used for gambling, many casinos seem to be out of luck when it comes to enforcing the debt owed on markers. ${ }^{20}$ Although the loans made directly from the casino to the gambler can be extremely risky, the casinos' interests also seem to be heavily favored in bankruptcy courts as their patrons are allowed fresh starts on their gambling-related credit card debts. ${ }^{21}$

\section{CHAPTER 7 REQUIREMENTS}

The Code exists to allow "honest but unfortunate debtors" to have a fresh start. ${ }^{22}$ An immediate question arises as to whether an addictive gambler constitutes an "honest but unfortunate debtor," but the legal analysis goes much further.

In 2005, Congress revised the Code through the Bankruptcy Abuse Prevention and Consumer Protection Act ("BAPCPA"). Through BAPCPA, Congress sought to make it tougher on consumers to actually discharge debts in bankruptcy ${ }^{23}$ The revisions set a clear standard that the court may dismiss a case for "abuse of the provisions" of Chapter $7 .{ }^{24}$ Additionally, BAPCPA deleted the presumption in favor of the debtor. ${ }^{25}$

${ }^{15} I d$.

${ }^{16} I d$.

${ }_{17} I d$. at 626.

${ }_{18}$ See generally id.

19 Id. at 626.

${ }^{20}$ See id. at 624; see also PNK (Lake Charles), LLC, v. Guevara (In re Guevara), 409 B.R. 442, 448, 450 (Bankr. S.D. Tex. 2009) (noting that while the public policy in some states has evolved, states traditionally oppose gambling for public policy purposes, and thus hold that gambling debts are unenforceable).

${ }_{21}$ See generally Matter of Totina, 198 B.R. 673 (Bankr. E.D. La. 1996); In re Cron, 241 B.R. 1 (Bankr. S.D. Iowa 1999); In re Baum, 386 B.R. 649 (2008); see also Jackson, The Fresh Start Policy in Bankruptcy Law, supra note 5 (referencing the "chains" that a gambler would be freed from upon a discharge of his or her credit card debts).

22 In re O'Brien, 328 B.R. at 674.

${ }^{23}$ See In re Batzkiel, 349 B.R. 581, 584 (Bankr. N.D. Iowa 2006).

${ }_{24} 11$ U.S.C. $\$ 707(b)(1)(2012)$.

${ }^{25}$ In re Batzkiel, 349 B.R. at 584. 
The Code prohibits the Chapter 7 discharge of debt from "luxury purchases" aggregating more than $\$ 500$ made within ninety days of the filing, which can often preclude the discharge of recent gambling debts. ${ }^{26}$ Additionally, some states hold that all gambling debts are entirely unenforceable, meaning that casinos - should they choose to operate in such states - may not be able to effectively sue for enforcement of debt owed through markers. ${ }^{27}$ Perhaps the most in-depth issue, and the issue on which this article will primarily focus, is the creditor's right to preclude a Chapter 7 discharge by showing that the debt was incurred under false pretenses or "bad faith." 28 Specifically, the Code provides that Chapter 7 does not entitle any debtor to a discharge of "any debt... for money ... to the extent obtained by ... false pretenses, a false representation, or actual fraud." 29

Unfortunately for creditors, proving that a debt was incurred under false pretenses is incredibly difficult. ${ }^{30}$ Most courts addressing the issue start with the presumption that the debtor intended to repay the debt at the time the loan was made. ${ }^{31}$ Courts then go through a multi-factor analysis for fraud to determine whether or not the gambler ever intended to pay back the cash advancement or other credit card debt. ${ }^{32}$ This analysis can be extremely fact specific and subjective, often allowing people to discharge the debt they incurred solely for their gambling habits. ${ }^{33}$

Under the current scheme, judgments against a debtor for intentional torts are non-dischargeable in Chapter $7 .^{34}$ Judgments simply for negligent or reckless torts, however, are still considered dischargeable debts. ${ }^{35}$ However, gambling debts are easily distinguishable from a basic negligent or reckless tort - such as an automobile accident - and thus deserve an exception. When a person takes borrowed money into a casino, he or she is directly using that loan in a negligent manner; the debtor is choosing to take borrowed money and "invest" in something that a reasonably prudent person knows will not payout. Congress needs to address this issue and bar the discharge of cash advances

${ }^{26} 11$ U.S.C. § 523(a)(2)(C) (2012). Luxury purchases include anything that "does not include goods or services reasonably necessary for the support or maintenance of the debtor or a dependent of the debtor." Id. Accordingly, money spent at a casino can be considered as a "luxury purchase."

27 See generally Joseph Kelly, Caught in the Intersection Between Public Policy

and Practicality: A Survey of the Legal Treatment of Gambling-Related

Obligations in the United States, 5 CHAP. L. REV. 87, 87-92 (2001).

${ }_{28} 11$ U.S.C. § 523(a)(2) (2012).

${ }^{29} \mathrm{Id}$.

${ }^{30}$ See infra Part III.

${ }^{31} I d$.

${ }^{32}$ See, e.g., In re Cron, 241 B.R. at 6.

${ }_{33}$ See infra Part III.

${ }^{34}$ See 11 U.S.C. § 523(a)(6) (2012).

${ }_{35}$ See Kawaauhau v. Geiger, 523 U.S. 57, $63-4$ (1998). 
that were used for gambling, as the debtor essentially negligently handled the cash obtained through the loan.

\section{RELEVANT CASES}

\section{A. Matter of Totina (1996)}

In Matter of Totina, a credit card company sought to have a Chapter 7 debtor's credit card cash advances that were used for gambling determined "non-dischargeable" for fraud. ${ }^{36}$ Here, the court looked at the debtor's subjective intent to repay the cash advances for purposes of the fraud discharge exception. ${ }^{37}$ Ultimately, the court held that the debts were dischargeable since the debtor intended to repay the cash advances when they were taken. ${ }^{38}$

The credit card company sought to have the $\$ 12,793.79$ in cash advancements that were used for gambling to be determined non-dischargeable under 11 U.S.C. $§ 523(\mathrm{a})(2)(\mathrm{A}){ }^{39}$ The Code states that a debt may not be dischargeable in Chapter 7 if that debt was incurred by false pretenses, a false representation, or actual fraud. ${ }^{40}$ The creditor argued that because the debtor obtained the cash advances knowing that he would use them to fund his gambling habit, the debts were incurred under false pretenses as the debtor likely only intended to repay the debt if he had a successful gambling spree. ${ }^{41}$ However, the party seeking to establish that a debt is non-dischargeable under the Code bears the burden of proof by a preponderance of the evidence. ${ }^{42}$ The court here applied a fact-intensive analysis to determine whether the debtor ever intended to repay the debts.

Because the debtor testified that he was trying to break his gambling habit and that he had a steady income at the time he incurred the debt, the court found that more likely than not the debtor had the subjective intent to pay back the cash advances at the time of the loan. ${ }^{43}$ Additionally, the court noted that "there is not a statutory rule that the use of credit cards to incur gambling debts shows the requisite intent of a debtor not to pay his debts." stated that "[i]f Congress intended that credit card advances for gambling losses be treated in any different fashion than any other debts incurred by an honest albeit, misinformed, and always overly optimistic — debtor, it can always

${ }^{36}$ Matter of Totina, 198 B.R. at 674.

${ }^{37} \mathrm{Id}$. at 680 .

${ }^{38} \mathrm{Id}$. at 681.

${ }^{39} \mathrm{Id}$. at 674.

4011 U.S.C. $\S 523(\mathrm{a})(2)(\mathrm{A})(2012)$.

41 See Matter of Totina, 198 B.R. at 675-76.

42 Grogan v. Garner, 498 U.S. 279, 280, 291 (1991).

${ }^{43}$ Matter of Totina, 198 B.R. at 680.

${ }^{44} I d$. at 681. 
amend the Code." 45 This case was decided before the BAPCPA revisions in 2005, but the decision may have been the same if it were decided today. Again, BAPCPA lowered the threshold from "substantial abuse" to simply "abuse" of the Code as grounds for dismissal. However, the court here focused on the subjective intent of the debtor at the time the cash advancement was made. ${ }^{46}$

\section{B. In re Cron (1999)}

In In re Cron, the Bankruptcy Court again held that a debtor's cash advances used for gambling were dischargeable in Chapter 7 bankruptcy. ${ }^{47}$ The court here considered numerous "intent factors" under Section 523 of the Code. In 1996, Mrs. Cron began gambling at a casino near her house, using only her Discover Credit Card at the casino. ${ }^{48}$ Cron testified that she always applied her winnings first and foremost to her Discover Card bill and any excess to her other debts. ${ }^{49}$ After incurring seventeen cash advances on her credit card and some other child care related expenses, Mrs. Cron filed for Chapter 7 bankruptcy. ${ }^{50}$

To prevail on a non-dischargeability action under Section 523, the creditor must prove fraudulent intent. ${ }^{51}$ In proving fraudulent intent, the Eighth Circuit required the creditor to prove: "that the debtor made a representation that was false; that the debtor realized the representation was false when it was made; that the debtor planned on the false representation misleading the creditor; that the creditor justifiably relied on the false representation; and that the creditor suffered a loss as a proximate result of that representation." 52 The court noted that since direct proof of fraudulent intent is so rare, the creditor may present circumstantial evidence to show the debtor's intent to deceive. ${ }^{53}$

As circumstantial evidence, the court looked at roughly a dozen factors in a balancing test fashion to find that the debtor did not have fraudulent intent. ${ }^{54}$ Specifically, the court noted that the debtor was a relatively sophisticated consumer, the debtor's financial condition was not hopelessly insolvent when she began gambling at the casino, the debtor was employed, the debtor's prospects for employment remained relatively the same, the debtor consulted a

${ }^{45} I d$.

${ }^{46} I d$. at $680-81$.

${ }^{47}$ In re Cron, 241 B.R. at 10.

${ }^{48} I d$. at 3.

${ }^{49} I d$.

${ }^{50} I d$. at $4-5$.

${ }^{51}$ See id. at 5.

${ }^{52}$ Id. (citing Caspers v. Van Horne (In re Van Horne), 823 F.2d 1285, 1287 (8th Cir.1987)).

${ }_{53} I d$. at 6 (citing In re Van Horne, 823 F.2d at 1287).

${ }^{54}$ Id. (citing AT \& T Card Servs. v. Ellingsworth (In re Ellingsworth), 212 B.R. 326, 335 (Bankr. W.D.Mo. 1997)). This list of factors is non-exhaustive, but helps the court assess debtor's credibility. Id. 
bankruptcy attorney after the advances were obtained, and the cash advances did not exceed the credit limit. ${ }^{55}$ In opposition to the debtor's argument, however, the court noted that the cash advances were not for necessities, that the debtor obtained seventeen cash advances in twenty-three days, and that there were multiple advances on most of the trips to the casino. ${ }^{56}$ In this detailed balancing test, the court held that the debtor met her burden of rebutting the non-dischargeability presumption under Section 523(a)(2)(C), as the evidence did not show any "fraudulent intent." 57

\section{In re Baum (2008)}

In a "post-BAPCPA" case, In re Baum, the debtor filed a Chapter 7 bankruptcy case in order to deal with debt arising out of a three or four month spree of internet gambling. ${ }^{58}$ The U.S. Trustee (UST), however, moved to have the case dismissed as an abuse of the Code.${ }^{59}$ Here, the debtor did not actually obtain "cash advances," but rather used her credit card to pay for playing on the online gambling websites. ${ }^{60}$ The debtor's addiction began affecting her daily life, as she would visit the gambling websites before work, during lunch, and after work. ${ }^{61}$ After several months, the debtor stopped gambling and sought a counselor for her addiction, but only after losing approximately $\$ 40,000$ to online gambling. ${ }^{62}$

Immediately after filing the case, the UST filed a motion to dismiss the case for abuse of Chapter $7 .{ }^{63} \mathrm{In}$ its motion, the UST argued that the "[d]ebtor's attempt to discharge her obligations to her creditors via Chapter 7 amounted to either bad faith or a dishonest relationship with her creditors, either of which would warrant dismissal for abuse under 11 U.S.C. § 707(b)." ${ }^{964}$ Additionally, the UST argued that the debtor "incurred debts knowing they were beyond her ability to repay, intent on keeping the winnings if she won while foisting the losses off on her creditors if she lost." ${ }^{65}$ In contrast, the debtor argued that she did intend to pay back the creditors when she incurred the debts, but the bills were much steeper than she anticipated and her efforts to repay failed. ${ }^{66}$ Unfortunately, this is a common situation for creditors with debtors who choose

${ }_{55}$ Id. at $9-10$.

${ }^{56} I d$.

57 Id. at 8-9.

58 In re Baum, 386 B.R. at 651.

${ }^{59} \mathrm{Id}$.

${ }^{60} I d$.

${ }^{61} I d$.

${ }^{62} I d$.

${ }^{63} I d$. at 651 .

${ }^{64} \mathrm{Id}$. at 651-52.

${ }_{65} \mathrm{Id}$.

${ }^{66} \mathrm{Id}$. 
to be irresponsible.

In these common situations, the UST again has the burden of proving that the debtor filed the petition in bad faith or that the totality of the circumstances of the debtor's financial situation demonstrates an abuse of the Code. ${ }^{67}$ The UST argued that the case was filed in bad faith because it was not prompted by a "sudden illness, calamity, disability, or employment." 68 Additionally, the UST argued that the debtor "recklessly gambled with other people's money, taking the risk that she would lose, and would therefore have to pay back the debts so incurred." 69

The court held that the debtor did not act in bad faith, as she intended to pay the credit card debts that she was accruing. ${ }^{70}$ The court in Baum relied on the established idea that "the representation made by the cardholder in a credit card transaction is not that he has an ability to repay the debt - it is that he has an intention to repay." 71 While acknowledging that the debtor was "extraordinarily careless" in accumulating such sums of debt in such a short period, nothing in the record suggested that she was deliberately incurring the debts with the intention of using Chapter 7 to escape them. ${ }^{72}$ Accordingly, the court found no "abuse" of the Code under Section $\S 707$ (b) and allowed the discharge of the debt. ${ }^{73}$

\section{DEFINING GAMBling For PURPOSES OF CHAPTER 7}

In order to regulate "gambling debts" under Chapter 7 of the Code, there must be some parameters to what exactly "gambling" means. Generally, states define gambling using three essential elements: consideration, chance, and a reward. ${ }^{74}$ Accordingly, any time a person pays money in exchange for the chance to win a prize, some form of gambling has occurred. This can become extremely intrusive, however, as miniscule bets placed between friends on things like sporting events technically constitutes "gambling."

For purposes of Chapter 7 and the non-dischargability of cash advances, the Code should look only to money spent in casinos or through online casinolike games. While the lottery is known as the "purest" form of gambling due to its absolute dependence on blind luck, the purchase of lottery tickets is rarely likely to lead to extensive debt that would result in a gambler filing for

${ }^{67} I d$.

${ }^{68} \mathrm{Id}$. at $653-54$.

${ }^{69} \mathrm{Id}$.

${ }^{70} I d$. at 654 .

${ }^{71}$ Id. (citing Rembert v. AT\&T Universal Card Servs., Inc. (In re Rembert), 141

F.3d 277 (6th Cir. 1998)).

${ }^{72} I d$.

${ }^{73}$ See id. at 656.

${ }^{74}$ Commonwealth v. Weisman, 479 A.2d 1063, 1065 (Pa. Super. Ct. 1984) (citing In re Gaming American Legion Post No. 109, 25 Pa. D. \& C.2d 572, 585 (1961)). 
bankruptcy. Additionally, games such as fantasy sports or a friendly wager with a friend are too attenuated to regulate properly. Thus, only money spent in brick-and-mortar casinos or online slot machines, blackjack, poker games, and the like should be seen as "non-dischargeable gambling debt" under Chapter 7 of the Code.

\section{Application OF TORT LAW TO GAMBLING CHOICES}

Instead of the tedious balancing tests currently applied, courts should find that debtors are per se negligent when they use cash advances from a financial institution to gamble. Today the standard for negligence is often known as the "Menlove standard," or specifically, "a failure to use that degree of care that a reasonably prudent person would have used under the same circumstances." 75 Additionally, the basic elements for proving negligence include a duty, a breach, causation, and damages. ${ }^{76}$ These four elements can be found in the situation at hand, meaning a debtor using borrowed money to gamble should be negligent per se.

When a person obtains a loan or cash advance from a credit card company, that person owes a duty to the company - the duty to pay back the loan. By filing for bankruptcy and attempting to discharge the cash advance, the person has breached that duty to the creditor. In such a situation, the cause of the breach is the debtor's choice to gamble with the money. The damages that occur, while sometimes small in comparison to other loans, should not be overlooked - the creditor essentially loses its money when the debtor files bankruptcy.

A deeper aspect of this analysis is establishing whether the debtor acted contrary to that of a reasonably prudent person. The courts currently look at the intent of the debtor at the time the cash advance was obtained. ${ }^{77}$ This is a poor analysis, however, as debtors can almost always convince a court that they "intended" to pay back the money at the time. ${ }^{78}$ Gamblers may essentially know that they will pay back the money once they win more, or at least break even. However, it can be argued that a reasonably prudent person would likely know that the odds are stacked against a gambler at a casino and therefore, the gambler will "more likely than not" lose money at the casino. Accordingly, when a person obtains a cash advance and chooses to use that money for

75 See Vaughan v. Menlove (1837) 173 Eng. Rep. 232, 232 (Ct. Com. Pl.); Common-Law Standard of Care-Negligence Defined-Generally, in 4C CoM. LITIG. IN N.Y. ST. CTS. § 88.91 (Robert L. Haig ed., 4th ed. 2015).

76 See e.g., Sanchez ex rel. Sanchez v. Wal-Mart Stores, Inc., 125 Nev. 818, 824, 221 P.3d 1276, 1280 (2009) ("It is well established that to prevail on a negligence claim, a plaintiff must establish four elements: (1) the existence of a duty of care, (2) breach of that duty, (3) legal causation, and (4) damages.").

77 See generally In re Baum, 386 B.R. at 654.

${ }^{78} \mathrm{Id}$. at 656. 
gambling, he or she should be considered to have acted contrary to a reasonably prudent person.

\section{Policy ARguments By GAMING COMMISSIONS}

State gaming commissions, which rely on gamblers spending money in casinos, likely approve of the current standard for dischargability. The easier it is for gamblers to discharge their gambling debts in bankruptcy, the more likely these gamblers are to willingly toss money into a casino game. With the current "intent" standard for dischargability, gamblers know that they essentially have a safety net for their gambling problem. If a person takes a cash advance to a casino, surely he or she intends to pay it back. Once reality sets in that the money is probably lost forever, the gambler simply resorts to Chapter 7 bankruptcy and deprives the creditor of its loan.

\section{Public Policy Arguments Against Promotion of GAmbling}

The public policy arguments against gambling have existed as long as gambling itself. Numerous groups such as the National Coalition Against Legalized Gambling (NCALG) or the National Council on Problem Gambling (NCPG) seek to stop compulsive gambling and fight against the legality of gambling in general. ${ }^{79}$ These groups would likely support a new negligence standard for dischargability under Chapter 7 for gambling debts, as seeing this spending as negligent would prevent gamblers from escaping their obligations to financial institutions and thereby discourage gambling.

\section{CONCLUSION}

The intersection of gaming law and bankruptcy law creates several interesting dilemmas for lawmakers. One major issue, however, is the ability to discharge gambling debts through Chapter 7 bankruptcy. Again, if the Code truly does exist only for the "honest but unfortunate debtor," then why are gambling debts dischargeable? On its face, gambling is a financially irresponsible decision simply based on the statistical chances of losing money. The court stated in Matter of Totina that "[i]f Congress intended that credit card advances for gambling losses be treated in any different fashion than any other debts... it can always amend the Bankruptcy Code;" this is exactly what Congress should do. ${ }^{80} \mathrm{~A}$ reasonably prudent person would not expect to take borrowed money into a casino and come out with the same ability to repay their creditor. Accordingly, credit card debts or cash advances that were used for gambling should not be dischargeable under the Code under any circumstances.

79 See About Us, NAT'L COUNSEL ON PROBLEM GAMBLING, https://www.ncp gambling.org/about-us/ (last visited Jan. 4, 2018); National Coalition Against Legalized Gambling, GAMBLING EXPOSED, http://www.gamblingexposed.org/ gamblingexposed_708-389-1127_008.htm (last visited Jan. 4, 2018).

${ }^{80}$ Matter of Totina, 198 B.R. at $\overline{676 .}$ 